This article was downloaded by: [UQ Library]

On: 19 November 2014, At: 11:33

Publisher: Taylor \& Francis

Informa Ltd Registered in England and Wales Registered Number:

1072954 Registered office: Mortimer House, 37-41 Mortimer Street, London W1T 3J H, UK

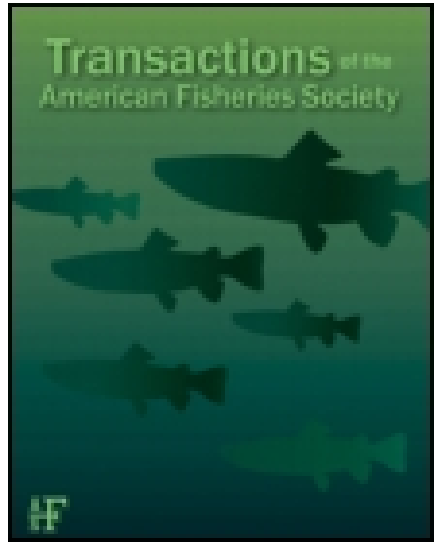

\title{
Transactions of the American Fisheries Society
}

Publication details, including instructions for authors and subscription information: http:// www.tandfonline.com/loi/ utaf20

\section{Protecting the Lobster}

Francis H. Herrick

Published online: $09 \mathrm{~J}$ an 2011.

To cite this article: Francis H. Herrick (1911) Protecting the Lobster,

Transactions of the American Fisheries Society, 40:1, 359-364, DOI: 10.1577/ 1548-8659(1910)40[359:PTL]2.0.CO;2

To link to this article: http://

dx. doi.org/ 10.1577/ 1548-8659(1910)40[359:PTL]2.0.CO;2

\section{PLEASE SCROLL DOWN FOR ARTICLE}

Taylor \& Francis makes every effort to ensure the accuracy of all the information (the "Content") contained in the publications on our platform. However, Taylor \& Francis, our agents, and our licensors make no representations or warranties whatsoever as to the accuracy, completeness, or suitability for any purpose of the Content. Any opinions and views expressed in this publication are the opinions and views of the authors, and are not the views of or endorsed by Taylor $\&$ Francis. The accuracy of the Content should not be relied upon and should be independently verified with primary sources of information. Taylor and Francis shall not be liable for any losses, actions, claims, proceedings, demands, costs, expenses, damages, and other liabilities whatsoever or howsoever caused arising directly or indirectly in connection with, in relation to or arising out of the use of the Content. 
This article may be used for research, teaching, and private study purposes. Any substantial or systematic reproduction, redistribution, reselling, loan, sub-licensing, systematic supply, or distribution in any form to anyone is expressly forbidden. Terms \& Conditions of access and use can be found at http://www.tandfonline.com/page/terms-andconditions 


\section{PROTECTING THE LOBSTER}

\section{By Francis H. Herrick}

The true condition of the lobster fishery cannot be determined from reports upon single regions or for single years. When long periods are considered the statistics as a whole present the clearest evidence of decline. In deciding the question of actual increase or decrease in the lobster, certain variables must be duly considered; yet, it is these highly important variable factors which are apt to be neglected. To state that more lobsters were captured one season than another, without a knowledge of the conditions under which these catches were made, affords no reliable basis for determining the true state of the fishery. We need to know also the numbers of men engaged, and of traps used, as well as the character of the areas fished, and the size of the animals caught.

The lobster fisheries of Canada, next to those of the codfish and salmon, are most valuable to the Dominion, and from 1869 to 1906 inclusive yielded a grand total of $\$ 83,291,553$. In 1897 the product of this industry was estimated at $23,721,554$ pounds, with a value of $\$ 3,485,265$. In 1906 , ten years later, in spite of rising prices, the yield had dropped to $20,241,764$ pounds, but though less than at the earlier time by nearly three and one half million pounds, this quantity had nearly the same value, namely, $\$ 3,422,927$. The greatest yield of this fishery is recorded for the years 1885 to 1887 , in 1886 reaching approximately $34,000,000$ pounds, these quantities in all cases representing the meat preserved in cans, and the animals shipped alive.

This great fishery has much to hope for in propagative measures of the right sort, and all persons the world over who like lobsters should welcome every sign of its actual increase. At the same time we should wish to know the truth of the matter, and a long memory is necessary. 
The produce of the Maine lobster fishery for 1907 is stated to have been between $8,000,000$ and $9,000,000$ pounds of lobsters $101 / 2$ inches and over in length. This seems a large quantity, but if we go back fifteen years, to 1892 , we find that it is only about one-half the amount recorded for that year, namely, 17,642,677 pounds. But is it not rather significant that the smaller quantity was worth in market nearly three times as much as the larger, or $\$ 2,000,000$ as compared with $\$ 663,043$ ? To catch the smaller number, moreover, required some 400 more men, using I do not know how many more traps, and working I cannot say how much wider or more diverse a field.

Now it is such facts as these which lead us to pause when we hear of increased yields to this industry, and inquire if our friend has duly considered the variables in his problem. For until he has done this his assertions have no value, and may be grossly misleading both to himself and to others. So far as I have been able to analyze statistics at present available the conclusion seems inevitable that the lobster fisheries in both America and Europe have steadily declined from the time when they began to be pursued with the means and energy characteristic of modern conditions, beginning in Canada nearly a quarter of a century ago. The cause of this decline is evident; more lobsters have been destroyed than nature has been allowed to replace by her slow processes of reproduction and growth.

How have we tried to check this declining tendency by legislative and other means? Various curative measures have been adopted, which will be discussed more fully in another place, but for the present we can dwell upon the two most important only, the gauge laws, and the practice of artificially hatching the eggs and immediately liberating the young in the sea. The first is prohibitory, penalizing the destruction and sale of lobsters of either sex under 9 or $10 \frac{1}{2}$ inches in length, while the second is a constructive measure, by means of which it is hoped to increase the species. 
I do not pretend to be able to award a just proportion of praise or blame for any measure or practice in such a matter, for I recognize that there are many doubtful factors in every biological problem, but I am forced to believe that both measures have been injurious to the interests of the entire fishery, the first by sanctioning the destruction of the best breeding stock, and the second by diverting large amounts of money and energy in an unproductive channel. The present gauge laws are a survival from the time when the biology of the lobster was not even approximately understood, and both measures seem to ignore or to neglect the law of survival, the importance of which can hardly be exaggerated. By the law of survival we mean the proportion of eggs or young which must survive and produce sexually mature animals in order to maintain the species at an equilibrium. It should be noted that while fishing has disturbed the equilibrium by reducing the number of adults, it has in no way affected the law of survival, which was presumably established at an earlier age, and which for all we now know to the contrary may persist until the race is extinct.

What is the rate of survival in the lobster? Since the sexes in this animal are approximately equal, and since to maintain the species it is necessary for each pair or for each mature female to produce only two adult individuals in the course of life, this rate would be expressed by the proportion $2: x$, in which $x$ represents the average number of eggs laid by a mature female during the whole of her life. While this average number cannot be determined directly, inasmuch as female lobsters are destroyed at all ages, an indication of it should be given by determining the average number of eggs carried by lobsters of every age or size. By an examination of 96,098 egg-bearing lobsters from Newfoundland, Allen found the average number to be 23,000 , which would correspond to a lobster 12 or $121 / 2$ inches long which had carried at least two broods, or 36,000 eggs in all. This would place the rate of survival at not less than 2 in 
30,000 , or 1 in 15,000 . A much higher rate was indicated for the Woods Hole region, although my examination covered only 4645 individuals. Now when we consider that 8-inch lobsters when at breeding age produce on the average 5000 eggs, and that a 17 -inch lobster, which must be at least twenty years old, has probably laid on an average nine batches of eggs to the number of 300,000 , the average number sought is bound to be high. We may consider 20,000 or even 30,000 , as a modest estimate, and well within the truth.

If the law of survival is a hard and stubborn fact, and if the average number of eggs approximates that given above, and I cannot see how such a conclusion can be avoided upon scientific grounds, their bearing upon the methods in question is evident. It means that this race of animals is maintained, not by paltry thousands, but by billions and hundred of billions of eggs. It means that the present and past gauge laws have been robbing this fishery of its best breeding stock, first because the breeding age is variable, and second because the number of eggs borne is proportional to the cube of the length of the mature animal. If the lobsters matured at a uniform age and size, and reached full breeding capacity at once, the question would be simplified, but neither of these conditions is fulfilled. The age of becoming mature covers a period corresponding to a length of a little over 7 inches to a length of a little over 12 inches, and probably not over 3 per cent of the 9-inch size, the legal gauge in certain states. have ever laid a single egg. Again owing to the rapid geometric increase in the product of eggs in relation to volume or size of the animal, the value of a 15 -inch lobster to the fishery is vastly greater than that of the 9 or 10-inch size. Under the present gauge laws the fishery is being steadily depleted of the eggs which it sorely needs, which it must have if it is ever to be rejuvenated, and which it can get only through its larger and best breeding animals. Protection of the female lobsters with eggs already attached to the body is only a 
palliative since one-half of all mature females are without eggs at all times of the year, and since there is an overlap of a few weeks in summer when practically no females carry eggs attached. These conditions are brought about by the fact that the breeding periods are, as a rule, two years apart, and by the further fact that the bulk of the old eggs hatch before the bulk of the new ones are laid.

The hatching of the eggs followed by the immediate liberation of the fry is ineffective, because it cannot be done on a scale commensurate with the requirements of nature, or upon any scale which can be deemed profitable. This is seen to be the case by applying the law of survival to the records of the hatcheries during the period of their greatest activities. Thus for the decennium 1893 to 1902 the combined hatcheries of Newfoundland, Canada, and the United States turned out, according to the records $4,214,000,000$ young lobsters. At a rate of survival of 1 in 15,000 , this would yield 280,933 adults, many of which would certainly never enter a trap. At the lower rate of 1 in 10,000 the number of survivors would be less than half a million. In other words, during the ten years in question there were added to the ocean by this means some half million lobsters, while at the same time its waters were depleted of from half a billion to a billion adults. This suggests drawing from the spigot while our barrel leaks from the bung. Where then is it best to make the sacrifice, for some sacrifice must be made. Plainly, it would seem, among the younger breeding adults. Eat the young, and better lobsters in the culinary sense, and save the older, and better in a biological sense, for breeding purposes, as has been urged by Dr. Field, of the Massachusetts Fish and Game Commission. We do not say destroy all the young, for that would be quickly fatal, but fortunately all the lobsters of any given size do not enter the traps; but protect the young and adolescents at the one end, say up to the 9-inch length, and the older lobsters at the other end, say after the 12 or the 13-inch length has been reached. In a word, put the 
better breeders in a growing and protected class, the animals which produce eggs by the twenty, forty and eighty thousand at a time. Stop the wasteful process of hatching the eggs and turning the helpless larvæ into the sea, but rear them, if possible, to the bottom-seeking stage, and then distribute them with the greatest care, as the Commission for Inland Fisheries of Rhode Island has wisely done through the efforts of Dr. Mead and his associates. What the rate of survival may be in the lobster at the fourth or fifth stage, when it seeks the bottom of its own accord, with brand new powers and instincts fitted to cope successfully with its environment, is not known, but it is safe to assume that it is a hundredfold, perhaps a thousand fold, greater than in the helpless state in which it leaves its mother and seeks the dangerous surface of the open sea.

\section{DISCUSSION}

Mr. J. W. Titcomb, Lyndonville, Vt.: I was very much interested in that paper and am entirely in accord with it. I think it has been demonstrated that the lobster can be reared to the fourth stage in the latitude of Maine just as easily as in the latitude of Rhode Island. It struck me that in Maine, where the difficulties of rearing are almost insurmountable owing to cost, it might be feasible to rear a portion to the fourth stage and to confine the plant of this portion to a certain part of the coast and other plants to another part of the coast, and watch results. It might be some indication as to the comparative results of planting millions of fry and planting a much smaller number of fourth stage lobsters on another part of the coast. The Bureau of Fisheries has found out that it can rear lobsters in Maine and I hope the work will be continued.

Mr. C. W. Willard, Westerly, R. I.: The Rhode Island Fish Commission through its superintendent has sent a paper to this meeting that will touch upon the very points named in the paper just read, which I appreciated highly and enjoyed listening to very much. I did not intend to have the paper read this afternoon for the reason that it seemed to me that there was sufficient outside of this paper to take up the attention of the meeting. However, if there is sufficient time, I think perhaps the members would be interested to hear this very short paper written by our superintendent, Mr. Barnes. The secretary has the paper. 